\title{
Tingkat Mortalitas Kelinci Prasapih di DKI Jakarta
}

\section{(Mortality Rate of Pre-weaning Rabbit in DKI Jakarta)}

\author{
Sudolar NR, Bahar S, Sente U \\ Balai Pengkajian Teknologi Pertanian Jakarta, Jl. Ragunan No. 30, Pasar Minggu, Jakarta Selatan 12540 \\ neng_dolar@yahoo.com
}

\begin{abstract}
Rabbit is the promising livestock to developed in Jakarta under small-scale or backyard systems. Low level of input, fast return and suitable to popularize in rural area were the merits of raising rabbit in DKI Jakarta. However, rabbit performances in several farmers were differed. The aim of present study was to measure the mortality rate of pre-weaning rabbit and to evaluate its causes. The data of pregnant rabbit since year of 2014 until 2016 were recorded for gestation period, month of parturition, level of parity, litter size, and total of pre-weaning losses. The result showed that mortality rate of rabbit in DKI Jakarta categorized as high, it is $61.88 \%$. From the observation, the main mortality factor was caused by failure of maternity behavior, followed by weak newborn, cannibalism of doe, technical cause such as trapped in the gap of wire of cage, lack milk production, desease, predators, climate, and death of doe.
\end{abstract}

Key Words: Rabbit, Mortality Rate, Pre-weaning, DKI Jakarta

\begin{abstract}
ABSTRAK
Kelinci adalah ternak yang berpotensi untuk dikembangkan di wilayah Jakarta dengan skala usaha kecil atau dengan sistem pemeliharaan di pekarangan. Input yang rendah, cepat menghasilkan dan sesuai untuk dipopulerkan di daerah perkotaan merupakan beberapa keuntungan dari memelihara kelinci di DKI Jakarta. Namun demikian, tingkat produktivitas kelinci pada beberapa peternak berbeda-beda. Salah satu faktor yang berpengaruh terhadap rendahnya tingkat produktivitas kelinci adalah tingginya tingkat kematian kelinci. Kegiatan ini dilakukan dengan tujuan untuk mengukur tingkat kematian anak kelinci prasapih dan mempelajari agen penyebabnya. Data kelinci bunting yang diambil mulai tahun 2014 sampai tahun 2016 dicatat lama kebuntingannya, tingkat paritas induk, ukuran anak, jumlah anak sekelahiran dan jumlah anak yang mati sebelum sapih. Hasil penelusuran menunjukkan bahwa tingkat mortalitas anak kelinci prasapih di DKI Jakarta tergolong tinggi yaitu sebesar 61,88\%. Dari hasil pengamatan, faktor penyebab utama kematian anak prasapih adalah kurangnya sifat keibuan, yang disusul dengan sebab lain yaitu lahir lemah, kanibalisme induk, penyebab teknis seperti terperangkap diantara celah kawat kandang saat lahir, tidak cukupnya produksi susu induk, hama, iklim, penyakit dan induk mati.
\end{abstract}

Kata Kunci: Kelinci, Tingkat Kematian, Prasapih, DKI Jakarta

\section{PENDAHULUAN}

Populasi ternak kelinci di DKI Jakarta selama kurun waktu 2012 hingga 2015 cenderung tidak mengalami peningkatan yang signifikan, dengan jumlah populasi kelinci tercatat sebanyak 188 ekor pada tahun 2015 (Ditjen PKH 2016). Namun saat ini, ternak kelinci sebagai diversifikasi ternak ruminansia maupun unggas mulai digalakkan untuk dikembangkan, tidak hanya di wilayah Jakarta tapi juga di berbagai wilayah lainnya. Kondisi di DKI Jakarta dengan keterbatasan lahan baik untuk pemeliharaan ternak ruminansia maupun penyediaan lahan rumput untuk sumber pakannya, menjadi faktor utama peralihan jenis ternak yang dikembangkan di DKI Jakarta dari ternak besar menjadi 
ternak berukuran kecil. Selain itu, merebaknya kasus flu burung beberapa waktu lalu telah memicu pemerintah DKI Jakarta untuk mengeluarkan regulasi terkait peternakan unggas pangan dengan lokasi peternakan minimal sejauh $25 \mathrm{~m}$ dari pemukiman melalui Perda DKI Jakarta No. 4 Tahun 2007. Peraturan tersebut akhirnya membatasi perkembangan peternakan unggas pangan di wilayah DKI Jakarta karena padatnya pemukiman penduduk.

Ternak kelinci dinilai mampu menjadi alternatif untuk diversifikasi protein hewani, baik dari segi nutrisi maupun kelayakan usahanya, dapat diusahakan baik oleh perorangan maupun badan usaha. Kecepatan reproduksi kelinci serta jumlah anakan yang umumnya tinggi, menjadi faktor pendorong bagi peternak untuk memelihara kelinci. Sebagai ternak multipara dengan tingkat efisiensi reproduksi yang tinggi, kelinci mampu melahirkan hingga sembilan ekor anak sekelahiran, dengan frekuensi bunting dapat mencapai delapan kali per tahun. Namun demikian, tingkat perkembangan ternak kelinci masih tergolong rendah, yang salah satunya dapat disebabkan oleh tingginya tingkat kematian kelinci.

Ternak kelinci dikenal sebagai ternak yang sulit dicegah dan diobati dari penyakit, terutama terkait fungsi pencernaan seperti kembung. Ternak terkadang ditemukan mati tanpa memperlihatkan gejala penyakit sebelumnya. Kondisi ini umumnya disebabkan ternak kelinci mengkonsumsi rumput atau pakan dengan kadar air tinggi sehingga menyebabkan kembung dan sering berakhir dengan kematian ternak. Namun, faktor-faktor apa saja yang menjadi penyebab kematian pada anak prasapih serta berapa tingkat kematian anak kelinci prasapih di DKI Jakarta, belum banyak dilaporkan. Maka, kegiatan ini bertujuan untuk mengukur tingkat kematian anak kelinci prasapih di Jakarta serta mengetahui faktor-faktor penyebabnya.

\section{MATERI DAN METODE}

\section{Materi}

Bahan yang dikumpulkan berasal dari data kelinci bunting dan melahirkan selama kurun waktu 2014 hingga 2016, baik yang dipelihara di BPTP Jakarta maupun di peternak kooperatif. Jenis kelinci yang digunakan merupakan peranakan New Zealand White yang dipelihara secara intensif dalam kandang battery berbahan kawat berukuran $70 \times 60 \times 40 \mathrm{~cm}$ dengan lebar celah antar kawat $1 \mathrm{~cm}$. Pakan utama kelinci berupa pelet, dengan air minum yang tersedia secara ad libitum. Proses perkawinan kelinci dilakukan secara alami dengan memasukkan kelinci betina ke kandang jantan hingga terjadi kopulasi. Proses perkawinan diusahakan terjadi hingga dua kali, kemudian kelinci betina dikembalikan ke kandangnya semula. Kotak beranak terbuat dari kayu dengan ukuran $37 \times 22 \times 13 \mathrm{~cm}$ dimasukkan ke dalam kandang menjelang kelahiran hingga anak mencapai umur tiga minggu. Anak disapih pada umur enam minggu. Kelinci betina pertama kali dikawinkan setelah mencapai umur enam bulan dan proses perkawinan kelinci diusahakan terus secara berkala hingga kelinci berumur dua tahun.

\section{Peubah dan analisis data}

Peubah yang diamati antara lain lama kebuntingan (hari), bulan melahirkan, tingkat paritas induk, jumlah anak sekelahiran dan jumlah anak yang mati sebelum sapih. Anak kelinci yang tidak disusui induk baik karena induk mati maupun induk tidak mau menyusui, dititipkan pada induk lain namun dihitung sebagai anak yang mati. Perilaku menyusui induk diamati melalui penampakan kondisi perut anak kelinci di pagi hari, apakah terlihat penuh atau kosong/kempes. Perut anak kelinci yang disusui akan terlihat menggembung. Data yang diperoleh kemudian dianalisis secara deskriptif. 


\section{HASIL DAN PEMBAHASAN}

Dari data reproduksi 80 kelahiran yang berasal dari 42 induk kelinci bunting dan melahirkan yang diambil dalam kurun waktu 2014-2016, diperoleh rata-rata jumlah anak sekelahiran yaitu 4,76 (dengan kisaran 1-9 anak) dengan rata-rata lama kebuntingan 31,69 hari. Dari total anak kelinci yang dilahirkan, tingkat kematian anak kelinci prasapih tergolong relatif tinggi, yaitu mencapai $67 \%$ dengan persentase kematian tertinggi terjadi pada saat anak berumur kurang dari satu minggu. Data reproduksi berdasarkan tingkat paritas induk disajikan pada Tabel 1 berikut.

Tabel 1. Data reproduksi kelinci bunting dan melahirkan (mean \pm SD) selama kurun waktu 20142016 berdasarkan paritas induk

\begin{tabular}{lcc}
\hline \hline Peubah & Paritas $1(\mathrm{~N}=23)$ & Paritas $>1(\mathrm{~N}=57)$ \\
\hline Lama kebuntingan (hari) & $31,57 \pm 1,93$ & $31,81 \pm 2,07$ \\
Jumlah anak (ekor) & $4,74 \pm 1,91$ & $4,79 \pm 1,94$ \\
Persentase anak disapih (\%) & $29,12 \pm 39,78$ & $36,92 \pm 39,47$ \\
Persentase anak mati $\leq 1$ minggu & $67,00 \pm 42,68$ & $58,87 \pm 41,06$ \\
Persentase anak mati $>1$ minggu & $3,88 \pm 9,22$ & $4,21 \pm 15,63$ \\
\hline
\end{tabular}

Data menunjukkan bahwa tingkat paritas induk tidak berpengaruh nyata pada tingkat kematian anak kelinci $(\mathrm{P}>0,05)$. Namun demikian, terdapat kecenderungan bahwa tingkat kematian anak sebelum umur satu minggu akan menurun seiring dengan bertambahnya tingkat paritas induk sesuai dengan yang dilaporkan oleh Rashwan \& Marai (2000). Dari hasil pengamatan, kematian anak kelinci prasapih disebabkan oleh berbagai faktor, antara lain induk yang tidak mau menyusui, anak lahir lemah atau lahir mati, kanibalisme induk, anak mati terperangkap di antara celah kandang, produksi susu induk tidak cukup, sakit, serangan hama tikus atau semut merah, iklim/suhu lingkungan dan induk mati. Persentase kematian anak kelinci prasapih berdasarkan penyebabnya dapat dilihat pada Gambar 1 berikut.

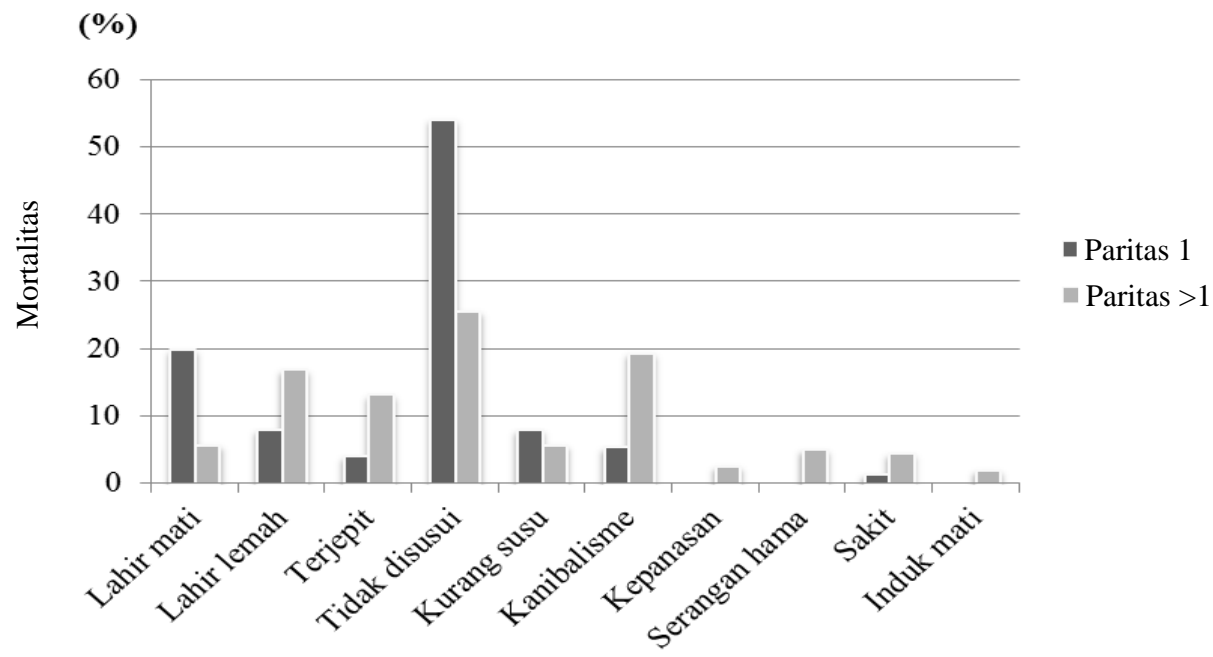

Gambar 1. Tingkat kematian anak kelinci prasapih berdasarkan penyebabnya

Tidak disusui induk merupakan faktor penyebab yang paling dominan pada kematian anak kelinci prasapih $(39,71 \%)$ dalam studi ini. Anak kelinci yang tidak disusui induknya sejak lahir, umumnya akan mati dalam kurun waktu maksimal tiga hari. Demikian juga 
yang direkomendasikan oleh Lebas et al. (1997) bahwa pengalihan anak ke induk asuh harus dilakukan hanya dalam kurun waktu tiga hari setelah lahir, dengan perbedaan usia anak tidak boleh lebih dari dua hari dan maksimal empat anak kelinci yang dialihkan ke satu induk asuh yang sama. Namun hasil survei di beberapa peternak kelinci menyebutkan bahwa susu induk yang kurang merupakan penyebab utama kematian anak kelinci prasapih yang disusul dengan faktor iklim (musim hujan), keberadaan predator berupa tikus, terjepit ataupun terinjak induknya, diare, suara petasan terutama di tahun baru dan lemah saat lahir (Bahar et al. 2014).

Hasil review Rashwan \& Marai (2000) juga menunjukkan bahwa jumlah produksi susu induk merupakan faktor paling penting terkait tingkat mortalitas anak. Demikian juga dengan hasil yang dilaporkan Pasupathi et al. (2014) bahwa kematian anak kelinci jenis New Zealand White yang dipelihara di Tamilnadu umumnya disebabkan karena kurangnya produksi susu induk sehingga anak menjadi lemah dengan kisaran angka kematian anak sekitar 2,34-15,23\%.

Salah satu faktor yang mempengaruhi jumlah produksi susu adalah jumlah asupan induk. Saat temperatur lingkungan melebihi $25^{\circ} \mathrm{C}$, maka asupan pakan induk akan berkurang (Cervera \& Carmona 2010). Temperatur di DKI Jakarta pada siang hari umumnya lebih dari $25^{\circ} \mathrm{C}$, bahkan dapat mencapai $33^{\circ} \mathrm{C}$ pada musim kemarau. Hal ini kemungkinan menjadi salah satu penyebab tidak optimalnya produksi susu induk sehingga kebutuhan nutrisi anak kurang tercukupi. Faktor produksi susu induk yang kurang menjadi penyebab kematian dari $6,74 \%$ anak.

Kejadian anak yang lahir lemah maupun lahir dalam keadaan mati, baik karena kelahiran prematur ataupun sebab lainnya, menjadi faktor penyebab kematian tertinggi selanjutnya setelah faktor tidak disusui induk. Minggu pertama merupakan masa dengan resiko tingkat kematian anak tinggi. Hal ini dapat diperburuk dengan banyaknya jumlah anak sekelahiran, sehingga tingkat persaingan anak untuk mendapatkan susu induk meningkat. Anak kelinci yang kalah bersaing akan memperoleh susu dalam jumlah yang kurang atau bahkan tidak dapat memperoleh susu induk. Anak kelinci ini akan semakin lemah dan umumnya tidak dapat bertahan hidup. Planinc et al. (2011) juga melaporkan bahwa kematian anak kelinci dipengaruhi oleh jumlah anak sekelahiran, musim serta bobot badan awal. Data menunjukkan tingkat kematian anak pada minggu pertama jauh lebih tinggi dibandingkan kematian anak setelah melewati umur satu minggu. Penurunan angka kematian anak kelinci seiring dengan pertambahan umur anak juga dilaporkan oleh Chandra et al. (2015).

Kanibalisme induk tercatat sebagai penyebab kematian dari 12,26\% anak prasapih. Persentase tersebut sedikit lebih rendah dari hasil Gonzalez-Redondo \& Zamora-Lozano (2008) dengan nilai 13,3\%. Kejadian kanibalisme yang ditemukan pada tiga induk kelinci, sifat kanibalisme persisten hanya terdapat pada satu induk, sedangkan dua induk lain yang menunjukkan kanibalisme kemungkinan besar dipicu oleh faktor nutrisi karena sedang terjadi perubahan pakan. Hal ini sesuai dengan literatur yang menyebutkan bahwa kanibalisme induk kelinci yang tidak persisten dapat dipicu oleh berbagai faktor, antara lain faktor defisiensi nutrisi maupun air minum, serta kehadiran rodensia atau binatang lain sesaat setelah induk melahirkan (Agricultural Communications 2017). Kanibalisme merupakan salah satu indikator penentu kualitas sifat keibuan seekor induk kelinci, selain kualitas sarang, serta persentase anak yang disusui setelah lahir. Induk dengan sifat keibuan yang rendah terlihat dari persiapannya untuk kelahiran anak yang tidak memadai serta anak yang berserak di luar kotak beranak (Denenberg et al. 1960). Kelinci dengan sifat keibuan yang tinggi umumnya akan mempersiapkan kelahiran anaknya dengan merontokkan bulu-bulunya, agar si anak merasa hangat. Sifat keibuan kelinci ini dilaporkan memiliki kaitan dengan fungsi bagian otak serta sistem hormonal (Cruz \& 
Beyer 1972; Gonzalez-Mariscal 2001; Gonzalez-Mariscal et al. 2003). Sifat keibuan rendah berdampak pada rendahnya angka anak kelinci yang berhasil hidup hingga sapih.

Faktor penyebab lainnya yaitu suhu tinggi pada saat musim kemarau tercatat menyebabkan heat stress dan berujung kematian pada beberapa anak kelinci. Aspek iklim yang juga disebutkan oleh Chandra et al. (2015) yaitu pada musim hujan, mengakibatkan tingkat kematian anak kelinci cenderung lebih tinggi. Hal ini dapat disebabkan oleh tingginya variasi temperatur lingkungan, kelembaban udara, serta suara petir yang memicu tingginya kejadian gangguan pernafasan, stres dan berbagai penyakit lainnya. Selaras dengan hasil yang disampaikan Zotte \& Paci (2013) bahwa musim saat beranak mempengaruhi tingkat kematian maupun performans anak kelinci. Data menunjukkan jumlah kelahiran tertinggi terjadi menjelang akhir tahun saat musim hujan berlangsung (Gambar 2).

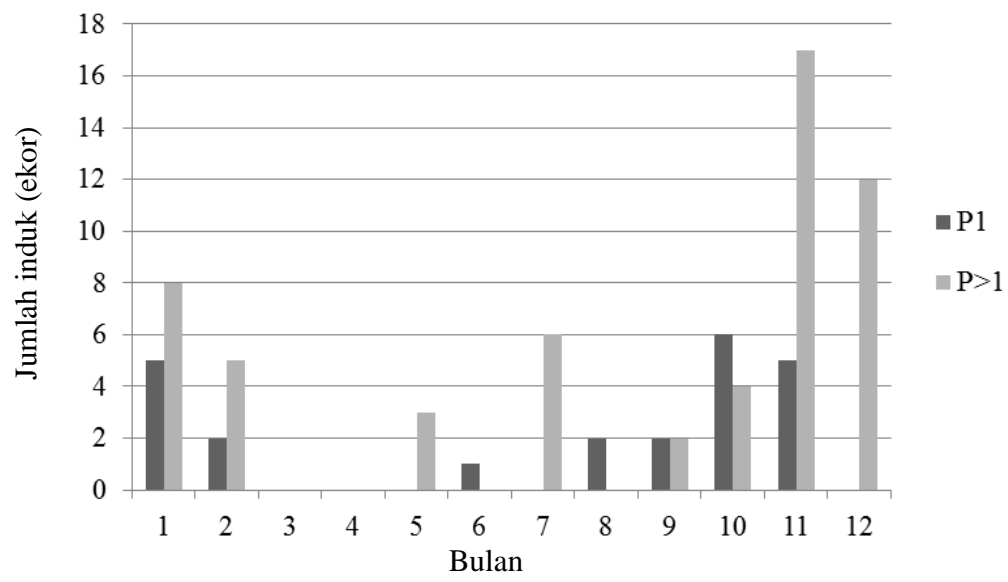

Gambar 2. Jumlah induk paritas $1(\mathrm{P} 1)$ dan induk paritas $>1(\mathrm{P}>1)$ yang melahirkan berdasarkan bulan dalam kurun waktu 2014-2016

\section{KESIMPULAN}

Dari data kelinci di DKI Jakarta yang dapat diamati dalam kajian ini, kurangnya sifat keibuan induk kelinci menjadi faktor utama penyebab tingginya tingkat mortalitas anak prasapih yang mencapai $67 \%$. Penyebab kematian anak prasapih lainnya antara lain induk yang tidak mau menyusui $(39,71 \%)$, anak lahir lemah $(12,66 \%)$ atau lahir mati $(12,33 \%)$, kanibalisme induk (12,26\%), anak mati terperangkap di antara celah kandang $(8,50 \%)$, produksi susu induk tidak cukup $(6,74 \%)$, sakit $(2,83 \%)$, serangan hama tikus atau semut merah $(2,48 \%)$, iklim/suhu lingkungan $(1,24 \%)$ dan induk mati $(0,93 \%)$.

\section{UCAPAN TERIMA KASIH}

Penulis mengucapkan kepada seluruh peternak kelinci kooperator di wilayah DKI Jakarta dan Bapak Nyoman (Yonif 201 Jaya Yudha).

\section{DAFTAR PUSTAKA}

Agricultural Communications. 2017. Rabbit cannibalism [Internet]. [cited 9 Februari 2017]. Available from: http://extension.msstate.edu/content/rabbit-cannibalism

Bahar S, Bakrie B, Sente U, Andayani D, Lotulung BV. 2014. Potensi dan peluang pengembangan ternak kelinci di wilayah perkotaan DKI Jakarta. Buletin Pertanian Perkotaan. 4:1-6. 
Cervera C, Carmona JF. 2010. Nutrition and the climatic environment. In: Nutrition of the rabbit. $2^{\text {nd }}$ ed. London (UK): CABI.

Chandra R, Karmakar HD, Chatlod LR, Rahman H. 2015. Pre-weaning mortality pattern in broiler rabbits in Sikkim. Indian Vet J. 92:96-100.

Cruz ML, Beyer C. 1972. Effects of septal lesions on maternal behavior and lactation in the rabbit. Physiol Behav. 9:361-365.

Denenberg VH, Petropolus SF, Sawin PB, Ross S. 1960. Genetic, physiology, and behavioral background of reproduction in the rabbit: VI. Maternal behavior with reference to scattered and cannibalized newborn and mortality. Behaviour. 15:71-76.

Ditjen PKH. 2016. Statistik peternakan dan kesehatan hewan 2016. Jakarta (Indonesia): Direktorat Jenderal Peternakan dan Kesehatan Hewan.

Gonzalez-Mariscal G. 2001. Neuroendocrinology of maternal behavior in the rabbit. Hormones Behav. 40:125-132.

Gonzalez-Mariscal G, Jimenez P, Beyer C, Rosenblatt JS. 2003. Androgens stimulate specific aspects of maternal nest-building and reduce food intake in rabbits. Hormones Behav. 43:312317.

Gonzalez-Redondo P, Zamora-Lozano M. 2008. Neonatal cannibalism in cage-bred wild rabbits (Oryctolagus cuniculus). Arch Med Vet. 40:281-287.

Lebas F, Coudert P, de Rochambeau, Thebault RG. 1997. Rabbitry management. In: The rabbit: Husbandry, health and production. Rome (Italy): Food and Agriculture Organization of the United Nations. p. 149-161.

Pasupathi K, Muthusamy P, Gopi H, Balasubramanyam D, Babu M. 2014. Survivability in New Zealand White breed of rabbits under farming condition in Tamilnadu. Int J Sci Environ Technol. 3:1772-1777.

Planinc M, Kermauner A, Malovrh S, Kovac M. 2011. Growth and mortality of SIKA suckling rabbits in Slovenia. Acta Agric Slovenia. 98:135-141.

Rashwan AA, Marai IFM. 2000. Mortality in young rabbits: A review. World Rabbit Sci. 8:111124.

Zotte AD, Paci G. 2013. Influence of rabbit sire genetic origin, season of birth and parity order on doe and litter performance in an organic production system. Asian-Australian J Anim Sci. 26:43-49.

\section{DISKUSI}

\section{Pertanyaan}

Apa tindakan yang dilakukan untuk mengatasi mothering ability pada kelinci?

\section{Jawaban}

Melakukan seleksi induk kelinci dan perbaikan pakan. 